\title{
PEMETAAN TATA KELOLA INFRASTRUKTUR PENYIARAN RADIO SWASTA DI DKI JAKARTA
}

\author{
Cosmas Gatot Haryono, T. Bambang Pamungkas \\ Universitas Bunda Mulia \\ Email :cgharyono@gmail.com,bambang_permadi2003@yahoo.com.sg
}

\begin{abstract}
$T$ he aims of this study is to conduct mapping related to the implementation of governance of private radio broadcasting in DKI Jakarta. This is interesting to do because there are many complaints from the public that the management of broadcast media in Jakarta, especially the Radio Private Broadcasting Institutions, deviates much from the rules stipulated in Law no. 32 of 2002 concerning Broadcasting. This research is a quantitative research with descriptive type that tries to see how the implementation of private radio management in Jakarta as the dependent variable. While the components seen are administrative data, broadcast program data, facilities and infrastructure development, and staffing data. The results obtained indicate that there are many irregularities in radio broadcasting management in DKI Jakarta, including related to share ownership by employees, time allocation for public service announcements, certified employees and ownership of standard infrastructure for broadcasting.
\end{abstract}

Keywords: Broadcast governance, Private radio, and Broadcast media

\begin{abstract}
ABSTRAK
$\mathrm{P}$ enelitian ini bertujuan untuk melakukan pemetaan terkait dengan implementasi tata kelola penyiaran radio swasta di DKI Jakarta. Hal ini menarik untuk dilakukan karena banyaknya keluhan dari masyarakat bahwa pengelolaan media siaran di Jakarta, khususnya Lembaga Penyiaran Swasta Radio banyak menyimpang dari aturan yang telah di tetapkan dalam Undang-undang no. 32 tahun 2002 tentang Penyiaran. Penelitian ini merupakan penelitian kuantitatif dengan jenis deskriptif yang mencoba melihat bagaimana pelaksanaan pengelolaan radio swasta di Jakarta sebagai variabel dependen. Sedangkan komponen yang dilihat adalah data administrasi, data program siaran, pengembangan sarana dan prasarana, dan data kepegawaian. Hasil yang diperoleh menunjukkan bahwa banyak terjadi penyimpangan dalam tata kelola penyiaran radio di DKI Jakarta antara lain terkait dengan kepemilikan saham oleh karyawan, alokasi waktu bagi iklan layanan masyarakat, karyawan yang bersertifikasi dan kepemilikan sarana prasarana standar untuk penyiaran.
\end{abstract}

Kata Kunci: Tata kelola penyiaran, Radio swasta, dan Media penyiaran

$66 \quad$\begin{tabular}{l|l} 
Islamic Communication Journal \\
Volume 5, Nomor 1, Januari-Juni 2020
\end{tabular} 


\section{PENDAHULUAN}

Di tengah perkembangan teknologi digital yang merambah dunia media saat ini, radio masih menjadi salah satu media yang cukup digemari masyarakat Indonesia. Meskipun tidak memiliki jumlah pendengar yang banyak, radio masih mempunyai penggemar yang loyal. Dengan konten yang banyak menyajikan bahasa gaul, radio bisa menjadi sarana hiburan yang cukup efektif untuk pendengarnya, karena dengan bahasa gaul pendengar bisa menjadi lebih akrab dan dekat, tidak hanya untuk pendengar dengan penyiar namun sesama pendengar dan pendengar dengan lingkungan sekitarnya (Theodora, 2013).

Data yang dikeluarkan beberapa lembaga survey menunjukkan bahwa radio merupakan media yang masih mendapatkan hati di kalangan pendengarnya. Nielsen Radio Audience Measurement (NRAM) melaporkan bahwa di kuartal ketiga tahun 2018 menunjukkan 57\% dari total pendengar radio berasal dari Generasi $\mathrm{Z}$ dan Millenials atau para konsumen masa depan (https://marketing.co.id/radio-masih-tetapdiminati/).

Sebagai media, siaran radio diselenggarakan dengan menggunakan jaringan siaran yang memanfaatkan spektrum udara yang dimiliki dan dikuasai oleh negara. Maka, setiap siaran radio wajib memiliki izin dan menaati aturan yang ditetapkan oleh negara (pemerintah). Di Indonesia sendiri, perangkat aturan yang mengatur persoalan penyiaran tertuang dalam Undang-Undang No. 32 tahun 2002 tentang Penyiaran. Di dalamnya diatur secara rinci pemanfaatan spektrum udara,
Cosmas Gatot Haryono, T. Bambang Pamungkas perizinan, dan pelaksanaan siaran baik oleh lembaga penyiaran publik, lembaga penyairan swasta, lembaga penyiaran komunitas, maupun lembaga penyiaran berlangganan.

Di Daerah Khusus Ibukota Jakarta, selain RRI sebagai lembaga siaran publik, terdapat banyak lembaga siaran radio, baik lembaga siaran radio komunitas, maupun lembaga siaran radio swasta. Menurut data Komisi Penyiaran Indonesia Daerah (KPID) DKI Jakarta, tercatat ada sekitar 4 lembaga siaran radio komunitas, 39 lembaga siaran radio swasta yang tersebar di lima wilayah kota Jakarta.

Sebagai lembaga siaran yang menggunakan spektrum udara yang dikuasai negara, seharusnya pengelola lembaga siaran swasta tunduk pada aturan yang tertera dalam Undang-Undang Penyiaran (UU No. 32 Tahun 2002). Tetapi faktanya banyak sekali pelanggaran yang sering kali ditemukan, mulai dari penyalahgunaan izin siaran, kelengkapan dan jangkauan siaran yang sering "diakali", hingga praktek monopoli dan kepemilikan ganda stasiun siaran radio. Hal ini menyebabkan terjadi pelanggaran terhadap hak-hak pendengar Jakarta yang seharusnya diperoleh ketika mendengarkan siaran radio.

Peneliti tertarik untuk melakukan pemetaan terhadap pengelolaan lembaga siaran radio swasta di Jakarta. Fokus penelitian ini adalah mengevaluasi penyelenggaraan siaran berdasarkan Undang-Undang no 32 tahun 2002 tentang penyiaran. Tujuan dari penelitian ini adalah untuk dapat memetakan lembaga siaran radio swasta mana yang sudah sesuai dengan ketentuan Undang-Undang dan lembaga

Islamic Communication Journal Volume 5, Nomor 1, Januari-Juni 2020 
Pemetaan Tata Kelola Infrastruktur...hal...66-82 siaran radio swasta mana yang tidak sesuai atau tidak menjalankan amanat UndangUndang.

Adapun lingkup pemetaan yang dilakukan pada lembaga siaran radio swasta di DKI Jakarta meliputi:

1. Data administrasi: termasuk didalamnya aspek pemodalan dan kepemilikan saham, aspek keuangan

2. Data program siaran: terdiri dari waktu siaran, sumber siaran, khalayak sasaran, prosentase genre siaran, dan daya saing

3. Pengembangan sarasan dan prasarana: termasuk di dalamnya perangkat studio dan perangkat siaran

4. Data kepegawaian: meliputi jumlah karyawan dan tingkat pendidikan.

\section{Komunikasi Massa}

Komunikasi massa tidak lagi hanya diartikan sebagai komunikasi untuk massa, tetapi lebih dari itu, komunikasi oleh media. Namun demikian, tidak berarti komunikasi massa adalah komunikasi untuk semua orang. Pada kenyataanya, media tetap cenderung memilih khalayaknya, dan sebaliknya khalayak juga memilih-milih media (River, 2003). Ada proses seleksi oleh media dan khalayak sendiri.

Ada beberapa karakteristik yang membedakan komunikasi massa dengan jenis komunikasi lainnya. William L. River (2003) menyebut ada lima karakteristik dasar komunikasi massa: bersifat satu arah, selalu ada proses seleksi, kompetisi yang Volume 5, Nomor 1, Januari-Juni 2020 ketat antar media, ditujukan untuk meraih khalayak sebanyak mungkin, dan dilakukan oleh institusi sosial yang harus peka terhadap kondisi sosial.

Media sendiri pada hakikatnya adalah perpanjangan lidah dan tangan yang berjasa meningkatkan kapasitas manusia untuk mengembangkan hidup dan struktur sosial penunjangnya (River, 2003). Walter Lippman (1992) mengatakan media mampu mempercepat, memperkuat dan melekatkan peran tradisional komunikasi. Ia menambahkan, media mempertebal dunia semu sehingga menambah jarak antara manusia modern dengan dunia nyata. Media telah menciptakan lingkungan semu tersendiri di antara manusia dan dunia "nyata" obyektif. Sebagai sumber pengetahuan, media menyajikan informasi dunia luar kepada orang, yang kemudian menggunakannya untuk membentuk atau menyesuaikan gambaran mentalnya tentang dunia.

Sementara Harold Laswell (1960) menjelaskan komunikasi massa sebagai suatu proses penyampaian pesan kepada komunikan melalui media dan menghasilkan efek tertentu. Efek inlah yang akan menentukan keberlanjutan komunikasi yang terjadi. Who says what, to whom, in what channel, with what effect.

Senada dengan Laswel, McQuail (2000) menekankan peran sentral media dalam komunikasi massa. Media massa tidak dilihat sekedar sebagai saluran komunikasi belaku, melainkan dilihat sebagai institusi, baik institusi ekonomi, sosial-budaya, maupun politik. 


\section{Radio Sebagai Media Massa}

Sebagai media, radio merupakan media yang tak lekang oleh waktu. Di tengah "gempuran" teknologi digital dan internet, tidak membuat media "tertelan" zaman. Radio masih menjadi media yang dicari oleh masyarakat. Tidak hanya kalangan tua, penggemar radio juga masuk di kalangan anak muda dan generasi milenial.

Sebagai media radio merupakan "bisnis telingan" (Rosalia, 2010); dimana cara kerjanya sangat mengandalkan audio, siaran radio mempunyai karakteristik penting yaitu auditori. Karakter auditori yang dimiliki oleh radio membuat proses komunikasi berjalan dengan lebih lancar dan santai. Auditori membuat komunikasi yang dilakukan melalui suara, dimana penyiar dapat menyampaikan berbagai bentuk pesan dengan lebih mudah.

Radio merupakan jenis media audio yang ekonomis, menyenangkan, dan paling murah. Menurut Anderson (1987: 127), media audio merupakan sumber bahan baku yang ekonomis, menyenangkan, dan mudah disiapkan untuk digunakan. Siaran radio melibatkan indera pendengaran, yang bersifat fleksibel, murah, praktis, dan dapat disampaikan dalam bentuk rekaman atau penyiaran. Dalam penyiaran radio, batasan pendengar, didasarkan pada suka atau tidak suka pada program siaran yang ditawarkan oleh stasiun penyiaran radio (Innayah \& Susanti, 2016).

Dalam konteks industri penyiaran, siaran radio memiliki dua komponen utama, yaitu pendengar dan pengiklan. Pendengar adalah sekumpulan orang yang mengkonsumsi siaran radio. Para pendengar
Cosmas Gatot Haryono, T. Bambang Pamungkas seharusnya merupakan pihak atau komponen paling penting atau sentral dari proses siaran karena pada dasarnya pendengar merupakan sasaran utama siaran radio. Sedangkan pengiklan adalah pihak lain yang rela mengeluarkan uang untuk beriklan di stasiun radio (MacLennan, 2018). Dari merekalah radio swasta bisa hidup karena stasiun radio memperoleh dana dari iklan-iklan yang mereka tempatkan di radio. Oleh karena itu, memberikan "service" yang baik kepada pengiklan akan memberikan jaminan pemasukan yang maksimal.

Dalam proses penyiarannya, siaran radio menggunakan spektrum frekuensi radio yang merupakan sumber daya alam yang terbatas dan mempunyai nilai strategis dalam penyelenggaraan telekomunikasi serta dikuasai oleh negara. Pemanfaatan spektrum frekuensi radio sebagai sumber daya alam tersebut perlu dilakukan secara tertib, efisien dan sesuai dengan peruntukannya sehingga tidak menimbulkan gangguan yang merugikan(http://www.pstel.go.id/

artike_c_3_-93. htm).

Alokasi spektrum siaran radio Indonesia ditetapkan dengan mengacu pada alokasi spectrum frekuensi radio internasional untuk wilatah 3 (tiga). Hal ini sesuai dengan Peraturan Radio yang ditetapkan oleh Himpunan Telekomunikasi Internasional (HTI).

\section{METODOLOGI PENELITIAN}

\section{Prosedur Penelitian}

Penelitian ini menggunakan metode penelitian deskriptif kuantitatif. Metode penelitian kuantitatif merupakan suatu metode penelitian yang berlandaskan pada 
Pemetaan Tata Kelola Infrastruktur...hal...66-82

filsafat positivisme, digunakan untuk meneliti pada populasi atau sampel tertentu, teknik pengambilan sampel pada umumnya dilakukan secara random, pengumpulan data menggunakan instrumen penelitian, analisis data bersifat kuantitatif/ statistik dengan tujuan untuk menguji hipotesis yang telah ditetapkan (Sugiyono, 2013: 13). Sedangkan pengertian deskriptif (ibid: 29) adalah metode yang berfungsi untuk mendeskripsikan atau memberi gambaran terhadap objek yang diteliti melalui data atau sampel yang telah terkumpul sebagaimana adanya, tanpa melakukan analisis dan membuat kesimpulan yang berlaku umum.

Senada dengan itu, Arikunto (2010) menjelaskan bahwa penelitian deskriptif tidak memiliki kekuatan untuk mengontrol hal-hal yang sementara terjadi, dan hanya dapat mengukur apa yang ada (exists). Penelitian jenis ini deskriptif merupakan penelitian yang dimaksudkan untuk mengumpulkan informasi mengenai status suatu gejala yang ada, yaitu keadaan gejala menurut apa adanya pada saat penelitian dilakukan.

Dalam penelitian deskriptif, sangat kecil peluang peneliti untuk menghubungkan fenomena yang diteliti dengan variabel lain atau menguji atau menjelaskan penyebab sistematisnya. Tujuan dari penelitian deskriptif sendiri adalah menggambarkan karakteristik atau perilaku suatu populasi dengan cara yang sistematis dan akurat. Biasanya, Penelitian deskriptif tidak didesain untuk menguji hipotesis, tetapi lebih pada upaya menyediakan informasi seputar karakter fisik, sosial, perilaku, ekonomi, atau psikologi dari sekelompok orang (Syamsudin \& Dimiyanti, 2011)

\section{Lokasi Penelitian}

Penelitian dilakukan di Daerah Khusus Ibu Kota yang meliputi 6 Wilayah Kota, yaitu Jakarta Pusat, Jakarta Timur, Jakarta Selatan, Jakarta Barat, Jakarta Utara dan Kepualuan Seribu.

\section{Populasi dan Sampel}

Yang menjadi populasi dalam penelitian ini adalah Lembaga Penyiaran Swasta (LPS) Radio radio. Di Daerah Khusus Ibukota Jakarta terdapat 39 Lembaga Penyiaran Swasta Radio. Masingmasing enam di Jakarta Barat, 14 di Jakarta Pusat, 16 di Jakarta Selatan dan 3 di Jakarta Timur. Maka ditetapkan populasinya adalah 39 LPS Radio. Melalui penghitungan Rumus Slovin dengan d: $10 \%$ diperoleh sampel sejumlah 19 LPS Radio.

\section{Variabel Penelitian}

Dalam penelitian ini hanya ada satu jenis variabel, yaitu: Pengelolaan Lembaga Penyiaran swasta Radio di Jakarta.

\section{Tabel 1. Operasionalisasi Variabel Penelitian}

\begin{tabular}{|l|l|l|}
\hline Variabel & Dimensi & Indikator \\
\hline Pengelolaan & 1. Data & a. Pemodalan \\
LPS Radio & administrasi & $\begin{array}{l}\text { b. kepemilikan } \\
\text { saham } \\
\text { DKI Jakarta }\end{array}$ \\
& & $\begin{array}{l}\text { c. aspek keuangan } \\
\text { a. waktu siaran }\end{array}$ \\
\hline
\end{tabular}




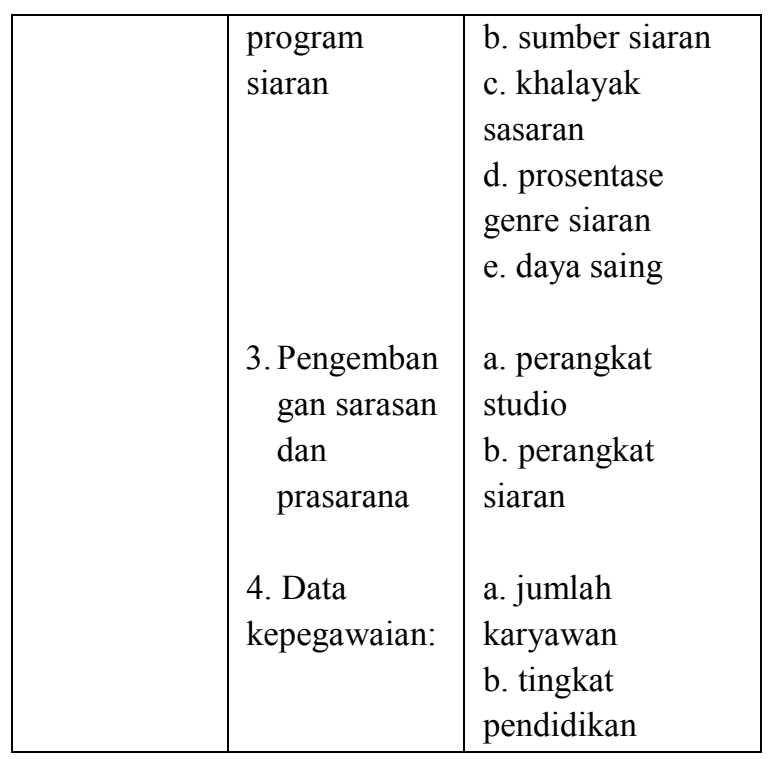

Penelitian ini dalam pengumpulan data menggabungkan survey, dokumentasi, dan wawancara. Teknik survey dilakukan sebagai cara untuk melakukan pengumpulan data awal melalui penyebaran kuisioner. Sedangkan metode dokumentasi adalah proses pencarian data mengenai hal-hal atau variabel yang berupa catatan, transkrip, buku, surat kabar, majalah, notulen rapat, agenda, dan sebagainya (Arikunto, 2010:274). Metode dokumentasi diawali dengan membuat check-list untuk mencari variabel yang sudah ditentukan. Apabila terdapat/muncul variabel yang dicari, maka peneliti tinggal membubuhkan tanda check a di tempat yang sesuai.

Peneliti menggunakan studi dokumentasi untuk mendukung hasil dari data yang diperoleh melalui angket yang telah dilakukan di lapangan sesuai dengan kebutuhan. Dokumentasi berupa foto-foto berkaitan dengan proses dan sarana prasarana, dan lampiran berbagai surat yang berkaitan dengan Lembaga Penyiaran Swasta Radio di DKI Jakarta.
Cosmas Gatot Haryono, T. Bambang Pamungkas Sedangkan wawancara dilakukan peneliti untuk memperoleh keterangan untuk memverifikasi sekaligus melengkapi data-data yang telah dikumpulkan melalui metode lainnya. Wawancara dilakukan melalui tanya jawab sambil bertatap muka antara si penanya atau pewawancara dengan si penjawab atau responden dengan menggunakan alat yang dinamakan interviewguide atau panduan wawancara (Nazir, 1988:146).

Analisis terhadap data yang telah diperoleh melalui survey dilakukan dalam dua tahap, yaitu tahap analisis data kuantitatif dan tahapan analisis data secara kualitatif. Dalam tahap analisis kuantitatif data diolah dan hasilnya disajikan dalam bentuk tabel. Selanjutnya untuk mempresentasekan hasil analisisnya dilakukan dengan menggunakan teknik deskriptif kualitatif. statistik deskriptif adalah statistik yang digunakan untuk menganalisis data dengan cara mendeskripsikan atau menggambarkan data yang telah terkumpul sebagaimana adanya tanpa bermaksud membuat kesimpulan yang berlaku untuk umum atau generalisasi (Sugiyono, 2011:207).

\section{HASIL PENELITIAN}

Sebagaimana dijelaskan pada bagian awal, penelitian ini dilakukan terhadap Lembaga Penyiaran Swasta (LPS) Radio yang ada di Daerah Khusus Ibukota Jakarta. Dari 39 Lembaga Penyiaran Swasta Radio yang ada, sampel yang dipilih peneliti berdasarkan penghitungan rumus solvin dengan d: $10 \%$, diperoleh sampel sejumlah 19 LPS Radio. Setelah disebarkan kuisioner, 
Pemetaan Tata Kelola Infrastruktur...hal...66-82 yang mengembalikan kusioner tersebut hanya 15 LPS Radio.

\section{Keuangan dan Operasional}

Terkait dengan kepemilikan saham, dari 15 stasiun swasta yang menjadi sampel tersebut, semua saham dimiliki oleh pengusahan dalam negeri. Tidak ada yang dimiliki oleh orang asing atau pihak asing yang mengatasnamakan pemodal dalam negeri. Sebenarnya kepemilikan saham oleh orang asing tidak dilarang dalam UndangUndang Penyairan No 32 tahun 2002 asalkan tidak lebih dari 20 persen. Pasal 17 ayat 2 menyatakan bahwa Lembaga Penyiaran Swasta dapat melakukan penambahan dan pengembangan dalam rangka pemenuhan modal yang berasal dari modal asing, yang jumlahnya tidak lebih dari 20\% (dua puluh per seratus) dari seluruh modal dan minimum dimiliki oleh 2 (dua) pemegang saham. Maka kepemilikan modal oleh pihak asing tidak menjadi masalah sepanjang mengikuti ketentuan yang berlaku.

Hasil penelitian yang dilakukan peneliti juga menemukan tidak adanya karyawan asing yang mengelola siaran radio. Seluruh karyawan yang bekerja adalah Warga Negara Indonesia dengan berbagai macam profesi. Undang-Undang Penyiaran sendiri mengamanatkan agar pengelola siaran radio swasta tdiak menempatkan orang asing pada posisi pengurus. Hal ini bukan berarti melarang seluruh orang asing bekerja di lembaga penyiaran swasta, karena undang-undang masih memberikan pengecualian pada bidang keuangan dan teknik. Undang-
Undang Penyiaran pasal 15 ayat 2 yang menyatakan bahwa warga negara asing dilarang menjadi pengurus Lembaga Penyiaran Swasta, kecuali untuk bidang keuangan dan bidang teknik.

Kelimabelas stasiun televisi tersebut tidak ada yang ada yang memiliki karyawan yang memiliki sahamnya. Padahal di pasal 17 ayat 3 UU Penyiaran mewajibkan karyawan diberikan kesempatan untuk memiliki saham. Ayat tersebut berbunyi: Lembaga Penyiaran Swasta wajib memberikan kesempatan kepada karyawan untuk memiliki saham perusahaan dan memberikan bagian laba perusahaan. Berarti banyak radio swasta yang tidak menjalankan amanat Undang-Undang Penyiaran tersebut.

Untuk membiayai keseluruhan jalannya perusahaan dan penyiaran hampir semua radio swasta di Jakarta mengandalkan iklan komersial sebagai sumber pendapatan dan pembiayaan operasional siaran. Sebagai lembaga penyiaran swasta yang tidak diperbolehkan mendapatkan dana bantuan operasional dari pemerintah, mereka mencari sumber pendanaan murni dari iklan yang mereka jual di sela-sela siaran.

\section{Tabel 2. Sumber Pembiayaan Radio Swasta DKI Jakarta}

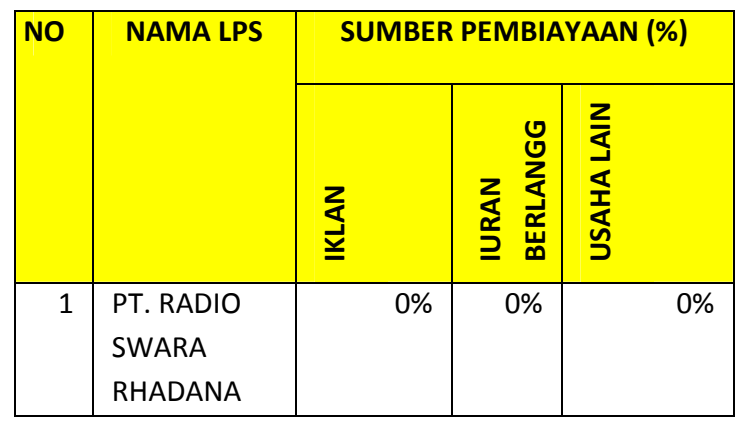




\begin{tabular}{|c|c|c|c|c|}
\hline & DUNIA & & & \\
\hline 2 & $\begin{array}{l}\text { PT. RADIO } \\
\text { KAYUMANIS }\end{array}$ & $100 \%$ & $0 \%$ & $0 \%$ \\
\hline 3 & $\begin{array}{l}\text { PT. RADIO } \\
\text { CAMAJAYA } \\
\text { SURYANA }\end{array}$ & $100 \%$ & $0 \%$ & $0 \%$ \\
\hline 4 & $\begin{array}{l}\text { PT. RADIO } \\
\text { KIRANA } \\
\text { INSAN } \\
\text { SUARA }\end{array}$ & $100 \%$ & $0 \%$ & $0 \%$ \\
\hline 5 & $\begin{array}{l}\text { PT. RADIO } \\
\text { MERPATI } \\
\text { DARMAWAN } \\
\text { GSA }\end{array}$ & $100 \%$ & $0 \%$ & $0 \%$ \\
\hline 6 & $\begin{array}{l}\text { PT. RADIO } \\
\text { MUSTANG } \\
\text { UTAMA }\end{array}$ & $100 \%$ & $0 \%$ & $0 \%$ \\
\hline 7 & $\begin{array}{l}\text { PT. RADIO } \\
\text { RAMAKO } \\
\text { DJAJA RAYA }\end{array}$ & $100 \%$ & $0 \%$ & $0 \%$ \\
\hline 8 & $\begin{array}{l}\text { PT. SUARA } \\
\text { IRAMA } \\
\text { INDAH }\end{array}$ & $100 \%$ & $0 \%$ & $0 \%$ \\
\hline 9 & $\begin{array}{l}\text { PT. RADIO } \\
\text { MUARA } \\
\text { ABDINUSA }\end{array}$ & $100 \%$ & $0 \%$ & $0 \%$ \\
\hline 10 & $\begin{array}{l}\text { PT. RADIO } \\
\text { ATTAHIRIYA } \\
\mathrm{H}\end{array}$ & $100 \%$ & $0 \%$ & $0 \%$ \\
\hline 11 & $\begin{array}{l}\text { PT. PESONA } \\
\text { GITA } \\
\text { ANINDITA }\end{array}$ & $100 \%$ & $0 \%$ & $0 \%$ \\
\hline 12 & $\begin{array}{l}\text { PT. RADIO } \\
\text { SUARA } \\
\text { KEDJAJAAN }\end{array}$ & $100 \%$ & $0 \%$ & $0 \%$ \\
\hline 13 & $\begin{array}{l}\text { PT. RADIO } \\
\text { ELSHINTA }\end{array}$ & $100 \%$ & $0 \%$ & $0 \%$ \\
\hline 14 & $\begin{array}{l}\text { PT. RADIO } \\
\text { INDIKA } \\
\text { MILLENIA }\end{array}$ & $95 \%$ & $3,5 \%$ & $1,5 \%$ \\
\hline 15 & $\begin{array}{l}\text { PT. RADIO } \\
\text { ANTAR } \\
\text { NUSA DJAJA }\end{array}$ & $100 \%$ & $0 \%$ & $0 \%$ \\
\hline
\end{tabular}

Sumber: Survey Peneliti

Hanya ada satu radio yaitu PT. Radio Indika Millenia, yang menyatakan memperoleh pendapatan lain di luar iklan. Radio yang dikenal dengan nama radio
Cosmas Gatot Haryono, T. Bambang Pamungkas Indika ini memperoleh sumber pendanaanya $95 \%$ didapatkan dari iklan, sedangkan sumber pendanaan lainnya diperoleh dari biaya berlangganan $(3,5 \%)$ dan pendapatan lainnya (1,5\%). Radio dengan nomer kanal FM 91,6 MHz ini memanfaatkan kerjasama dengan TV berlangganan untuk memperoleh pelanggan.

\section{Isi Siaran dan Iklan}

Sebagian besar Lembaga Penyiaran Radio Swasta DKI Jakarta merupakan radio hiburan, hanya Elshinta FM yang mengklaim dirinya sebagai radio berita dan pendidikan. Tidak semua radio siaran swasta tersebut menyelenggarakan siarannya selama 24 jam dalam sehari. Tercatat dari 15 stasiun siaran radio yang disurvey, ada sekitar 10 yang melakukan siaran hingga 24 jam dalam sehari. Sedangkan lima stasiun lainnya, yaitu radio Camajaya FM, Radio Cosmopolitan FM, Radio Brava FM, Radio Trax FM, dan Hard Rock FM mengudara di Jakarta sekitar 18 jam. Untuk menyelenggarakan siaran selama beberapa jam tersebut, dibutuhkan banyak sekali konten siaran. Penyelenggara siaran bisa memperoleh konten siaran tersebut dari berbagai sumber, antara lain: inhouse production, akuisisi, dan penjualan.

Bila dilihat dari sumber materi siaran yang diberikan kepada publik, mayoritas radio swasta di Jakarta memperolehnya dari inhouse production. Artinya, sebagian besar radio di Jakarta memproduksi sendiri siaran yang akan disiarkan kepada publik. Tercatat hanya beberapa radio saja yang bekerjasama ataupun mengakuisisi program siaran dari pihak lain. Berdasarkan survey yang peneliti lakukan, tercatat hanya tiga radio yang tidak

Islamic Communication Journal

Volume 5, Nomor 1, Januari-Juni 2020 
Pemetaan Tata Kelola Infrastruktur...hal...66-82

murni memproduksi materi radio secara mandiri, yaitu Radio Camajaya FM, Gen FM, dan radio Elshinta dengan prosentasi materi siaran dari luar yang sangat kecil. Radio Camajaya FM bekerjasama dengan pihak lain dalam produksi materi siaran sebesar $10 \%$, sedangkan $90 \%$ lainnya mereka lakukan produksi sendiri atau inhouse production. Radio Gen FM memproduksi meteri siaran secara inhouse sebanyak $85 \%$, bekerja sama dengan pihak lain untuk melakukan produksi materi siaran sebanyak $10 \%$ dan $5 \%$ materi siaran lainnya merupakan akuisisi materi siaran. Sedangkan radio Elshinta FM, melakukan produksi siarannya secara inhouse production sebesar $90 \%$ dan menyiarkan materi siaran hasil dari kerja sama dengan pihak lain sebesar $10 \%$.

Dilihat dari sisi muatan konten siarannya, hampir semua stasiun melakukan siaran dengan mengikuti ketentuan isi siaran sebagaimana diatur dalam Undang-Undang Penyiaran pasal 36 ayat 3 yang berbunyi Isi siaran dari jasa penyiaran televisi, yang diselenggarakan oleh Lembaga Penyiaran Swasta dan Lembaga Penyiaran Publik, wajib memuat sekurang-kurangnya 60\% (enam puluh per seratus) mata acara yang berasal dari dalam negeri. Meskipun demikian, prosentasenya memang terdapat ketidakseragaman. Meskipun sama-sama memegang izin sebagai lembaga siaran radio swasta lokal, muatan konten siaran tidak ada kesamaan satu sama lainnya.

\section{Tabel 2. Kategori Isi Siaran Radio Swasta Di DKI Jakarta}

\begin{tabular}{|c|c|c|c|c|}
\hline \multirow[t]{2}{*}{ NO } & \multirow[t]{2}{*}{ NAMA LP } & \multicolumn{3}{|c|}{ KATEGORI ISI SIARAN (\%) } \\
\hline & & 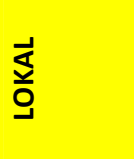 & $\begin{array}{l}\frac{1}{5} \\
\frac{2}{5} \\
\frac{0}{z}\end{array}$ & 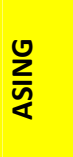 \\
\hline 1 & $\begin{array}{l}\text { PT. RADIO } \\
\text { SWARA } \\
\text { RHADANA DUNIA }\end{array}$ & $0 \%$ & $0 \%$ & $0 \%$ \\
\hline 2 & $\begin{array}{l}\text { PT. RADIO } \\
\text { KAYUMANIS }\end{array}$ & $60 \%$ & $0 \%$ & $40 \%$ \\
\hline 3 & $\begin{array}{l}\text { PT. RADIO } \\
\text { CAMAJAYA } \\
\text { SURYANA }\end{array}$ & $0 \%$ & $90 \%$ & $10 \%$ \\
\hline 4 & $\begin{array}{l}\text { PT. RADIO } \\
\text { KIRANA INSAN } \\
\text { SUARA }\end{array}$ & $80 \%$ & $0 \%$ & $20 \%$ \\
\hline 5 & $\begin{array}{l}\text { PT. RADIO } \\
\text { MERPATI } \\
\text { DARMAWANGSA }\end{array}$ & $100 \%$ & $0 \%$ & $0 \%$ \\
\hline 6 & $\begin{array}{l}\text { PT. RADIO } \\
\text { MUSTANG } \\
\text { UTAMA }\end{array}$ & $80 \%$ & $0 \%$ & $20 \%$ \\
\hline 7 & $\begin{array}{l}\text { PT. RADIO } \\
\text { RAMAKO DJAJA } \\
\text { RAYA }\end{array}$ & $90 \%$ & $0 \%$ & $10 \%$ \\
\hline 8 & $\begin{array}{l}\text { PT. SUARA } \\
\text { IRAMA INDAH }\end{array}$ & $60 \%$ & $40 \%$ & $0 \%$ \\
\hline 9 & $\begin{array}{l}\text { PT. RADIO } \\
\text { MUARA } \\
\text { ABDINUSA }\end{array}$ & $70 \%$ & $20 \%$ & $10 \%$ \\
\hline 10 & $\begin{array}{l}\text { PT. RADIO } \\
\text { ATTAHIRIYAH }\end{array}$ & $90 \%$ & $0 \%$ & $10 \%$ \\
\hline 11 & $\begin{array}{l}\text { PT. PESONA GITA } \\
\text { ANINDITA }\end{array}$ & $70 \%$ & $20 \%$ & $10 \%$ \\
\hline 12 & $\begin{array}{l}\text { PT. RADIO SUARA } \\
\text { KEDJAJAAN }\end{array}$ & $70 \%$ & $20 \%$ & $10 \%$ \\
\hline 13 & $\begin{array}{l}\text { PT. RADIO } \\
\text { ELSHINTA }\end{array}$ & $30 \%$ & $60 \%$ & $10 \%$ \\
\hline 14 & $\begin{array}{l}\text { PT. RADIO INDIKA } \\
\text { MILLENIA }\end{array}$ & $40 \%$ & $40 \%$ & $20 \%$ \\
\hline 15 & $\begin{array}{l}\text { PT. RADIO ANTAR } \\
\text { NUSA DJAJA }\end{array}$ & $70 \%$ & $30 \%$ & $0 \%$ \\
\hline
\end{tabular}

Sumber: Survey Peneliti 
Beberapa Radio siaran swasta DKI Jakarta menyiarkan berbagai konten siaran dengan mengkombinasikan muatan lokal, nasional dan asing. Ada yang muatan lokalnya sama dengan muatan nasional. Misalnya, radio Indika FM, seluruh konten siarannya bermuatan lokal $40 \%$, muatan nasional $40 \%$ dan muatan asingnya $20 \%$. Ada juga yang mempunyai muatan lokal lebih sedikit dibandingkan muatan nasional. Misalnya, Radio Elshinta muatan lokalnya lebih sedikit, yaitu hanya sekitar $30 \%$ sedangkan $70 \%$ dari siarannya bermuatan nasional. Hal ini terkait dengan jenis siaran yang dilakukan oleh Elshinta yang pada dasarnya merupakan radio berita. Bahkan ada stasiun radio swasta lokal Jakarta yang tidak ada sama sekali muatan lokalnya, yaitu Radio Camajaya FM tidak menampilkan muatan lokal sama sekali, melainkan $100 \%$ muatan nasional.

Ada juga radio swasta lokal yang mengkombinasikan siaran lokal dengan konten asing yang cukup besar. Misalnya Female Radio, menyelenggarakan siaran dengan konten asing hingga $40 \%$ dari keseluruhan siaran yang mereka lakukan; sedangkan $60 \%$ lainnya mengandung konten siaran lokal. Beberapa radio swasta mengkombinasikan muatan lokal, nasional dan asing dengan proporsi yang menempatkan muatan lokal cukup banyak. Misalnya Mustang FM dan KISS FM $80 \%$ mengandung muatan lokal, sedang $20 \%$ sisanya muatan asing.

Sedangkan bila dikaitkan dengan durasi iklan layanan masyarakat maupun iklan komersialnya, ada beberapa fenomena yang menarik. Dimana hampir semua radio tidak menampilkan tidak lebih dari 20
Cosmas Gatot Haryono, T. Bambang Pamungkas persen sehari. Dalam Undang-Undang Penyiaran pasal 46 ayat 8 disebutkan bahwa "Waktu siaran iklan niaga untuk Lembaga Penyiaran Swasta paling banyak 20\% (dua puluh per seratus), sedangkan untuk Lembaga Penyiaran Publik paling banyak 15\% (lima belas per seratus) dari seluruh waktu siaran". Dengan demikian, iklan komersial boleh dilakukan dengan tidak melebihi $20 \%$ waktu siaran dalam sehari. Bila semua melakukan siaran 24 jam penuh dalam sehari, maka $20 \%$ waktu siaran adalah 4,8 jam atau sekitar 288 menit. Bila melihat hasil survey yang peneliti lakukan, tidak ada satupun radio swasta yang melakukan siaran iklan niaga melebihi ketentuan UU Penyiaran. Rata-rata mereka menyiarkan iklan niaga tidak lebih dari 200 menit per hari.

Tetapi hal itu tidak terjadi pada penayangan iklan layanan masyarakat. Ada beberapa radio swasta di DKI Jakarta yang masih belum menjalankan peraturan tentang iklan layanan masyarakat dengan benar. Pada ayat 9 UU Penyiaran menyebutkan bahwa waktu siaran iklan layanan masyarakat untuk Lembaga Penyiaran Swasta paling sedikit 10\% (sepuluh per seratus) dari siaran iklan niaga, sedangkan untuk Lembaga Penyiaran Publik paling sedikit 30\% (tiga puluh per seratus) dari siaran iklannya. Berarti dalam satu hari, sebuah radio swasta harus menayangkan iklan layanan masyarakat rata-rata selama 28.8 menit dalam sehari. Dari hasil survey yang peneliti lakukan, beebrapa radio swasta di Jakarta yang tidak memenuhi tuntutan UU Penyiaran tersebut. Dari 13 radio swasta yang memberikan isian pada kolom waktu iklan layanan masyarakat, masih ada empat 
Pemetaan Tata Kelola Infrastruktur...hal...66-82 stasiun radio yang belum memenuhi amanat UU penyiaran tersebut, yaitu Radio Muara Abdinusa (Cosmopolitan FM), Radio Pesona Gita Anindita (Brava Radio), Radio Suara Kedjayaan (Trax FM), dan Radio Antar Nusa Djaya (Hard Rock FM).

Tabel 3. Waktu Iklan Rata-Rata per Hari

\begin{tabular}{|r|l|r|r|}
\hline NO & \multicolumn{1}{|c|}{ NAMA LP } & \multicolumn{2}{|c|}{ WAKTU RATA-RATA } \\
IKLAN/ HARI (menit)
\end{tabular}

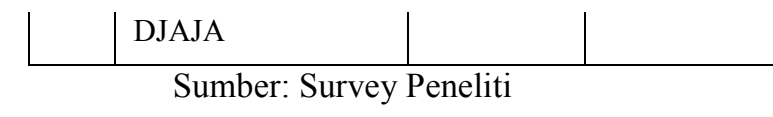

\section{Sarana dan Prasarana}

Sarana dan prasarana yang dimaksudkan peneliti di sini adalah perlengkapan siaran yang meliputi kepemilikan kantor, studio tetap, studio mobile (bergerak) dan pemancar. Dalam pasal 31 ayat 1 UU no 32 tahun 2002 tentang Penyiaran menjelaskan bahwa Lembaga penyiaran yang menyelenggarakan jasa penyiaran radio atau jasa penyiaran televisi terdiri atas stasiun penyiaran jaringan dan/atau stasiun penyiaran lokal.

Dari hasil survey yang peneliti lakukan, hampir semua radio swasta di Jakarta tidak memiliki kantor sendiri. Mereka memilih untuk melakukan sewa daripada memiliki gedung sendiri. Hal ini terkait dengan kemudahan dalam pengelolaan dan pemeliharaan bangunan yang memang menghabiskan biaya yang cukup besar. Berdasarkan survey peneliti yang lakukan terhadap 15 stasiun radio swasta di DKI Jakarta, hanya satu stasiun radio yang memiliki kantor atau gedung sendiri, yaitu radio Camajaya FM yang berlokasi di Jl Kayu Putih VI D/8 Jakarta Timur.

Tabel 4. Sarana Dan Prasarana Radio Swasta di DKI Jakarta

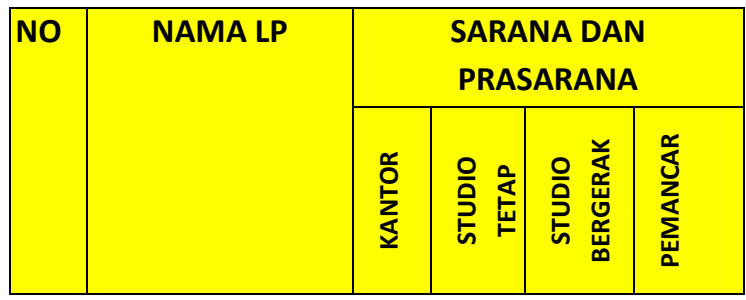




\begin{tabular}{|c|c|c|c|c|c|}
\hline 1 & $\begin{array}{l}\text { PT. RADIO SWARA } \\
\text { RHADANA DUNIA }\end{array}$ & $\sum_{\tilde{N}}^{0}$ & $\stackrel{\text { 兰 }}{\bar{\varepsilon}}$ & $\frac{\frac{1}{\pi}}{\frac{\pi}{+0}}$ & $\stackrel{\text { 兰 }}{\bar{\varepsilon}}$ \\
\hline 2 & $\begin{array}{l}\text { PT. RADIO } \\
\text { KAYUMANIS }\end{array}$ & 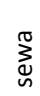 & 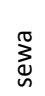 & $\stackrel{\text { 站 }}{\underline{\varepsilon}}$ & $\stackrel{\text { 兰 }}{\bar{\varepsilon}}$ \\
\hline 3 & $\begin{array}{l}\text { PT. RADIO } \\
\text { CAMAJAYA } \\
\text { SURYANA }\end{array}$ & 兰 & 鸢 & $\frac{.2}{\frac{\pi}{0}}$ & 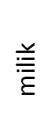 \\
\hline 4 & $\begin{array}{l}\text { PT. RADIO KIRANA } \\
\text { INSAN SUARA }\end{array}$ & 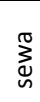 & $\stackrel{\text { 兰 }}{\underline{\underline{\varepsilon}}}$ & $\frac{\text { 并 }}{\frac{0}{+}}$ & $\stackrel{\text { 兰 }}{\bar{\varepsilon}}$ \\
\hline 5 & $\begin{array}{l}\text { PT. RADIO MERPATI } \\
\text { DARMAWANGSA }\end{array}$ & 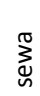 & $\stackrel{\text { 站 }}{\underline{\varepsilon}}$ & $\frac{.2}{\frac{\pi}{0}}$ & 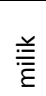 \\
\hline 6 & $\begin{array}{l}\text { PT. RADIO } \\
\text { MUSTANG UTAMA }\end{array}$ & 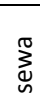 & $\stackrel{\underline{\underline{\underline{\varepsilon}}}}{\underline{\underline{\varepsilon}}}$ & $\frac{.2}{\frac{\pi}{0}}$ & 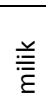 \\
\hline 7 & $\begin{array}{l}\text { PT. RADIO RAMAKO } \\
\text { DJAJA RAYA }\end{array}$ & 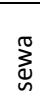 & $\stackrel{\underline{\underline{\underline{E}}}}{\underline{\underline{E}}}$ & $\frac{\frac{.2}{\pi}}{\frac{\pi}{+0}}$ & $\stackrel{\text { 站 }}{\underline{\varepsilon}}$ \\
\hline 8 & $\begin{array}{l}\text { PT. SUARA IRAMA } \\
\text { INDAH }\end{array}$ & 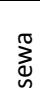 & $\stackrel{\text { 美 }}{\underline{E}}$ & $\frac{\text { 임 }}{\frac{\pi}{0}}$ & $\stackrel{\text { 站 }}{\text { है }}$ \\
\hline 9 & $\begin{array}{l}\text { PT. RADIO MUARA } \\
\text { ABDINUSA }\end{array}$ & 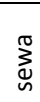 & $\stackrel{\text { 兰 }}{\bar{\varepsilon}}$ & $\stackrel{\text { 兰 }}{\bar{\varepsilon}}$ & $\stackrel{\text { 妾}}{\underline{\xi}}$ \\
\hline 10 & $\begin{array}{l}\text { PT. RADIO } \\
\text { ATTAHIRIYAH }\end{array}$ & 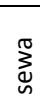 & $\stackrel{\underline{\underline{\underline{E}}}}{\underline{\underline{E}}}$ & $\frac{\frac{.2}{\pi}}{\frac{\pi}{+0}}$ & $\stackrel{\text { 妾 }}{\bar{\varepsilon}}$ \\
\hline 11 & $\begin{array}{l}\text { PT. PESONA GITA } \\
\text { ANINDITA }\end{array}$ & 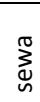 & 兰 & 荡 & 总 \\
\hline 12 & $\begin{array}{l}\text { PT. RADIO SUARA } \\
\text { KEDJAJAAN }\end{array}$ & 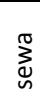 & 兰 & 兰 & $\stackrel{\text { 兰 }}{\underline{\bar{\varepsilon}}}$ \\
\hline 13 & $\begin{array}{l}\text { PT. RADIO } \\
\text { ELSHINTA }\end{array}$ & 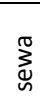 & 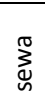 & 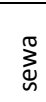 & 兰 \\
\hline 14 & $\begin{array}{l}\text { PT. RADIO INDIKA } \\
\text { MILLENIA }\end{array}$ & 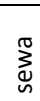 & 兰 & 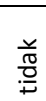 & 总 \\
\hline 15 & $\begin{array}{l}\text { PT. RADIO ANTAR } \\
\text { NUSA DJAJA }\end{array}$ & 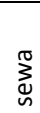 & 鸢 & 兰 & $\stackrel{\text { 兰 }}{\underline{\bar{\varepsilon}}}$ \\
\hline
\end{tabular}

Sumber: Survey Peneliti

Untuk studio tetap sebagian besar telah memilikinya secara mandiri. Hanya ada dua stasiun radio swasta yang mengaku menyewa studio tetap, yaitu Female FM dan Radio Elshinta FM. Dari 15 Stasiun Radio swasta yang peneliti survey, hanya sedikit yang memiliki stasiun radio bergerak
Cosmas Gatot Haryono, T. Bambang Pamungkas sehingga bisa menopang siaran di luar ruang secara mobile. Tercatat hanya enam lembaga radio swasta, yaitu Female FM, Cosmopolitian FM, Brava Radio, Trax FM, Elshinta FM, dan Hard Rock FM. Sembilan lembaga siaran radio swasta lainnya tidak memilikinya. Sementara untuk pemancar, semua stasiun radio swasta tersebut memiliki perlengkapan pemancaran sendiri, sehingga tidak perlu menyewa kepada pihak ketiga.

\section{Kepegawaian}

Dari hasil survey yang peneliti lakukan, ditemukan bahwa pegawai dari 15 stasiun radio swasta di Jakarta rata-rata merupakan lulusan sarjana. Meskipun demikian, ada beberapa radio yang masih mengangkat pegawai lulusan D3 dan SMA. Biasanya mereka ditempatkan pada posisi teknisi yang memang bertugas support terhadap keberlangsungan siaran.

\section{Tabel 5. Struktur Pendidikan Pegawai Radio Swsta di Jakarta}

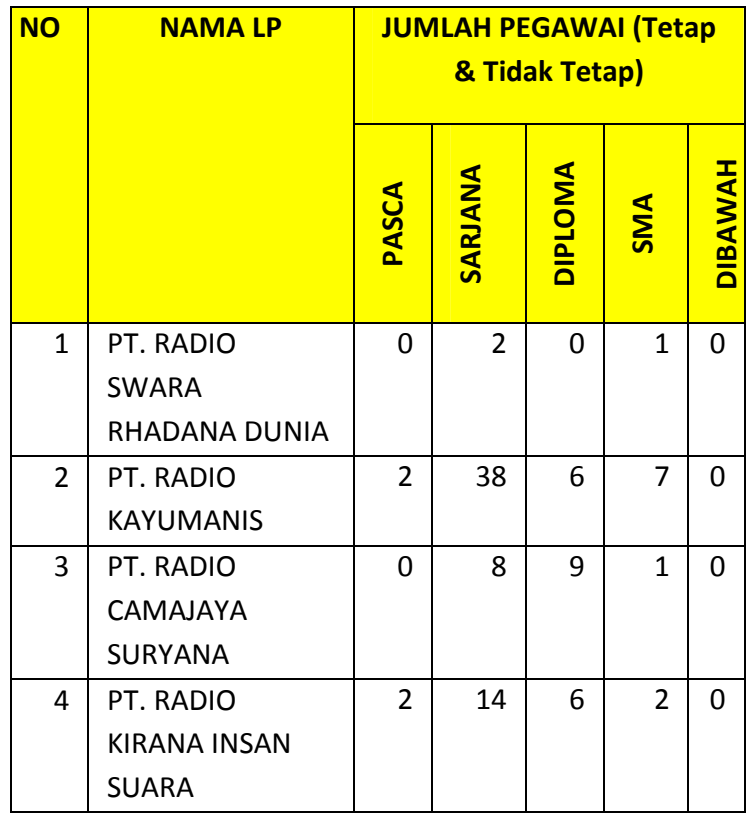

Islamic Communication Journal Volume 5, Nomor 1, Januari-Juni 2020 
Pemetaan Tata Kelola Infrastruktur...hal...66-82

\begin{tabular}{|c|c|c|c|c|c|c|}
\hline 5 & $\begin{array}{l}\text { PT. RADIO } \\
\text { MERPATI } \\
\text { DARMAWANGSA }\end{array}$ & 0 & 22 & 3 & 1 & 0 \\
\hline 6 & $\begin{array}{l}\text { PT. RADIO } \\
\text { MUSTANG } \\
\text { UTAMA }\end{array}$ & 0 & 19 & 2 & 2 & 0 \\
\hline 7 & $\begin{array}{l}\text { PT. RADIO } \\
\text { RAMAKO DJAJA } \\
\text { RAYA }\end{array}$ & 3 & 13 & 2 & 2 & 0 \\
\hline 8 & $\begin{array}{l}\text { PT. SUARA } \\
\text { IRAMA INDAH }\end{array}$ & 2 & 49 & 8 & 22 & 0 \\
\hline 9 & $\begin{array}{l}\text { PT. RADIO } \\
\text { MUARA } \\
\text { ABDINUSA }\end{array}$ & 0 & 32 & 3 & 4 & 1 \\
\hline 10 & $\begin{array}{l}\text { PT. RADIO } \\
\text { ATTAHIRIYAH }\end{array}$ & 1 & 40 & 8 & 14 & 0 \\
\hline 11 & $\begin{array}{l}\text { PT. PESONA GITA } \\
\text { ANINDITA }\end{array}$ & 0 & 19 & 1 & 3 & 0 \\
\hline 12 & $\begin{array}{l}\text { PT. RADIO SUARA } \\
\text { KEDJAJAAN }\end{array}$ & 0 & 24 & 1 & 8 & 0 \\
\hline 13 & $\begin{array}{l}\text { PT. RADIO } \\
\text { ELSHINTA }\end{array}$ & 3 & 97 & 7 & 23 & 1 \\
\hline 14 & $\begin{array}{l}\text { PT. RADIO INDIKA } \\
\text { MILLENIA }\end{array}$ & 0 & 14 & 8 & 15 & 0 \\
\hline 15 & $\begin{array}{l}\text { PT. RADIO ANTAR } \\
\text { NUSA DJAJA }\end{array}$ & 0 & 44 & 4 & 7 & 1 \\
\hline
\end{tabular}

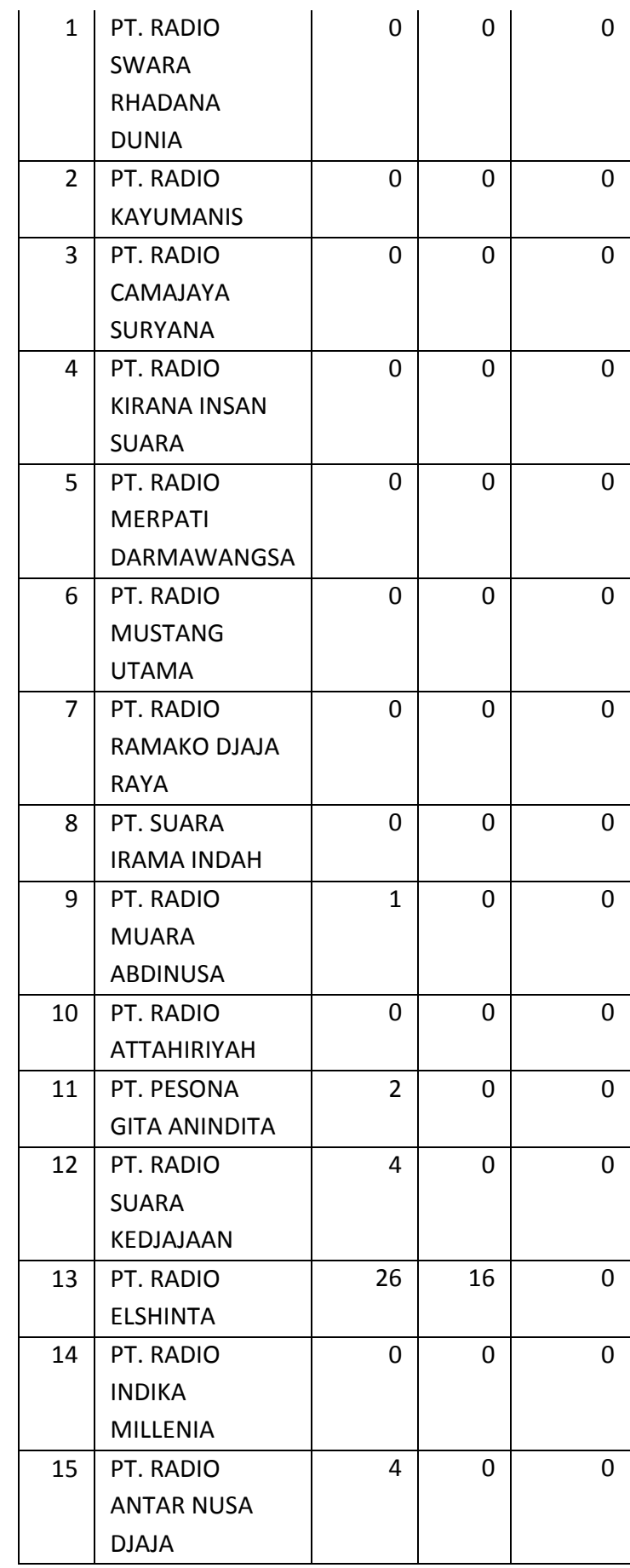

Sumber: Survey Peneliti

Untuk sertifikasi penyiaran internasional tidak ada satupun radio swasta di DKI Jakarta yang memilikinya. Sedangkan yang mengikuti sekolah P3 \&S

$78 \quad \begin{aligned} & \text { Islamic Communication Journal } \\ & \text { Volume 5, Nomor 1, Januari-Juni } 2020\end{aligned}$ 
PS juga hanya lima stasiun radio, yaitu: Cosmopolitan FM (1 pegawai), Brava FM (2 pegawai), Trax Fm (4 pegawai), Elshinta (26 pegawai), dan Hard rock FM (4 pegawai).

\section{Pembahasan: Masih Ada Pelanggaran}

Penyelenggaran siaran radio swasta di DKI Jakarta masih jauh dari kata ideal. Masih terdapat berbagai persoalan terutama berkaitan dengan pelaksanaan amanat Undang-Undang Penyiaran no 32 tahun 2002. Terdapat kecenderungan ketidakpatuhan penyelenggara siaran terhadap amanat Undang-Undang dalam berbagai aspek penyiaran.

Pada aspek keuangan dan pengelolaan, ditemukan bahwa hampir semua stasiun radio swasta Jakarta tidak memberikan sebagian kepemilikan sahamnya kepada karyawan. Padahal dengan jelas, UU No. 322002 tentang penyiaran pasal 17 ayat 3 mengamanatkan agar lembaga Penyiaran Swasta memberikan kesempatan karyawan untuk memiliki saham. Ayat tersebut berbunyi: Lembaga Penyiaran Swasta wajib memberikan kesempatan kepada karyawan untuk memiliki saham perusahaan dan memberikan bagian laba perusahaan. Ternyata tidak ada LPS Radio DKI Jakarta yang patuh terhadap ketentuan ini.

Terkait dengan kategori konten siarannya, semua stasiun telah memenuhi standar yang ditetapkan oleh pemerintah.dalam Undang-Undang Penyiaran pasal 36 ayat 3 yang berbunyi: Isi siaran dari jasa penyiaran televisi, yang diselenggarakan oleh Lembaga Penyiaran Swasta dan Lembaga Penyiaran Publik, wajib memuat sekurang-kurangnya 60\%
Cosmas Gatot Haryono, T. Bambang Pamungkas (enam puluh per seratus) mata acara yang berasal dari dalam negeri. Meskipun demikian, prosentasenya memang terdapat ketidakseragaman. Meskipun sama-sama memegang izin sebagai lembaga siaran radio swasta lokal, muatan konten siaran tidak ada kesamaan satu sama lainnya.

Hanya saja masih ada stasiun radio yang tidak menyiarakan konten lokal sama sekali (lihat Tabel 2). Ini tentu bertentangan kebijakan KPI (Komisi Penyiaran Indonesia) yang menghendaki adanya miniman $10 \%$ muatan konten lokal untuk Penyelenggara Siaran Swasta. Padahal banyak sekali kotenkonten lokal Jakarta yang bisa dieksplorasi untuk menjadi konten siaran yang menarik.

Terkait dengan iklan layanan masyarakat, sebagaimana diamanatkan UU Penyiaran pasal 46 ayat 9 UU Penyiaran menyebutkan bahwa waktu siaran iklan layanan masyarakat untuk Lembaga Penyiaran Swasta paling sedikit 10\% (sepuluh per seratus) dari siaran iklan niaga, sedangkan untuk Lembaga Penyiaran Publik paling sedikit 30\% (tiga puluh per seratus) dari siaran iklannya. Pada kenyataanya, masih ada beberapa radio swasta di DKI Jakarta yang masih belum menjalankan peraturan tentang iklan layanan masyarakat dengan benar. Dari 13 radio swasta yang memberikan jawaban pada kolom waktu iklan layanan masyarakat (lihat Tabel 3), masih ada empat stasiun radio yang belum memenuhi amanat UU penyiaran tersebut, yaitu Radio Muara Abdinusa (Cosmopolitan FM), Radio Pesona Gita Anindita (Brava Radio), Radio Suara Kedjayaan (Trax FM), dan Radio Antar Nusa Djaya (Hard Rock FM).

\section{Islamic Communication Journal Volume 5, Nomor 1, Januari-Juni 2020}


Pemetaan Tata Kelola Infrastruktur...hal...66-82

Selain itu, ada juga persoalan di aspek personalia. Masih banyak stasiun radio swasta DKI Jakarta yang belum memiliki karyawan yang bersertifikasi penyiaran. Sebagian besar pegawai mereka tidak pernah mengikuti sertifikasi penyiaran dan Sekolah P3 \& SPS. Masih sangat sedikit radio swasta yang memiliki pegawai bersertifikat penyiaran baik nasional maupun internasional. Berdasarkan survey, tercatat hanya satu stasiun radio swasta yang memiliki pegawai bersertifikasi penyiaran nasional, yaitu radio Elshinta sebanyak 16 pegawai (Lihat Tabel 6).

Tidak ada satupun radio swasta di DKI Jakarta yang memiliki sertifikasi penyiaran dengan level internasional. Sedangkan yang mengikuti sekolah P3 \&S PS juga hanya lima stasiun radio, yaitu: Cosmopolitan FM (1 pegawai), Brava FM (2 pegawai), Trax Fm (4 pegawai), Elshinta (26 pegawai), dan Hard rock FM (4 pegawai).

Yang cukup mengejutkan, peneliti menemukan ternyata hampir semua radio swasta di Jakarta tidak memiliki kantor sendiri. Mereka memilih untuk menyewa daripada memiliki gedung sendiri. Hal ini terkait dengan kemudahan dalam pengelolaan dan pemeliharaan bangunan yang memang menghabiskan biaya yang cukup besar. Berdasarkan survey yang peneliti lakukan terhadap 15 stasiun radio swasta di DKI Jakarta (lihat Tabel 4), hanya satu stasiun radio yang memiliki kantor atau gedung sendiri, yaitu radio Camajaya FM yang berlokasi di Jl. Kayu Putih VI D/8 Jakarta Timur. Padahal dalam pasal 31 ayat 1 UU no 32 tahun 2002 tentang Penyiaran secara jelas mengatakan bahwa Lembaga penyiaran yang menyelenggarakan jasa penyiaran radio atau jasa penyiaran televisi terdiri atas stasiun penyiaran jaringan dan/atau stasiun penyiaran lokal. Maka seharusnya seluruh stasiun penyiaran memiliki perangkat siaran secara mandiri sehingga bisa menyelenggarakan jasa siaran. Bukan justru menyewa dari pihak lain.

Berbagai penyimpangan tersebut harus segera dibenahi karena bagaimanapun juga, lembaga penyiaran swasta menggunakan frekuensi public yang seharusnya digunakan untuk public dengan pelayanan terbaik. Sebagai bentuk pertanggungawaban mereka terhadap masyarakat, stasiun radio swasta sewajarnya melakukan praktek penyiaran yang sesuai dengan pedoman penyiaran nasional Indonesia (UU No. 32 Tahun 2002 Tentang Penyiaran).

\section{KESIMPULAN}

Dari beberapa temuan di atas dapat disimpulkan bahwa banyak terjadi penyimpangan dalam tatakelola penyiaran radio di DKI Jakarta selama ini. Masih banyak lembaga siaran radio swasta yang tidak menaati Undang-Undang Penyiaran sebagai pedoman siaran mereka sehari-hari. Penyimpangan itu antara lain terkait dengan: a). kepemilikan saham oleh karyawan yang tidak dijalankan oleh semua stasiun radio swasta di DKI Jakarta; b). lokasi waktu bagi iklan layanan masyarakat minimal $10 \%$ dari seluruh iklan komersialnya dalam dalam sehari yang belum dipenuhi oleh semua stasiun swasta di DKI Jakarta; c). masih banyaknya radio swasta di DKI Jakarta yang belum memiliki karyawan yang 
bersertifikasi (P3 \& SPS ataupun internasional); dan d). kepemilikan sarana prasarana standar untuk penyiaran.

Oleh karena itu peneliti menyarankan Komisi Penyiaran Indonesia Daerah (KPID) DKI Jakarta untuk kerja keras, memberikan dorongan bagi lembaga siaran radio Swasta untuk memperbaiki diri dan memenuhi amanat Undang-Undang Penyiaran. Bila hal ini dibiarkan, tentu saja akan merugikan masyarakat DKI Jakarta. Dibutuhkan keberani KPID DKI Jakarta untuk menegur atau bahkan memberikan sanksi kepada lembaga-lembaga siaran swasta yang memang tidak serius menjalankan amanat Undang-Undang Penyiaran. Hal ini perlu dilakukan karena sebenarnya yang dirugikan dan dipertaruhkan adalah masa depan masyarakat Jakarta yang menikmati siaran radio.

\section{DAFTAR PUSTAKA}

Anderson, Ronald H. (1987). Pemilihan dan Pengembangan Media untuk Pembelajaran. Jakarta: Universitas Terbuka bekerja sama dengan CV. Rajawali.

Arikunto, S. (2010). Manajemen penelitian . Jakarta: Rineka Cipta.

Lasswell, Harold. (1960). The Structure and Function of Communication in Society, dalam Mass Communications, a Book of Readings Selected and Edited by the Director of the Institute for Communication Research at Stanford University. Editor:
Cosmas Gatot Haryono, T. Bambang Pamungkas

Wilbur Schramm. Urbana: University of Illinois Press

Lippman, Walter, (1992). Public Opinion, London: Transaction Publisher

McQuail, Denis, dan Windahl, Sven. (1993). COMMUNICATION MODELS For the study of mass communications (Second edition). London and Newyork: Longman.

McQuail, Denis. (2000). Mass Communication Theory. London, Thousand Oaks, New Delhi: SAGE Publications.

Nazir. (1988). Metode Penelitian, Jakarta: Ghalia

River, William L. et.al. (2003). MediaMassa \& Masyarakat Modern. Jakarta: Kencana

Sugiyono. (2013). Metode penelitian kuantitatif, kualitatif dan $R \& D$. Bandung: Alfabeta.CV

\section{Jurnal:}

Innayah dan Mariana Susanti. (2016). Peran Serta Pendengar dan Lembaga Pemerintah dalam Siaran Radio Pendidikan. Jurnal Pekommas, Vol. 1 No. 1: 21 - 32

MacLennan, AnneFrances. (2018). Private Broadcasting and the Path to Radio Broadcasting Policy in Canada. Media and Communication Jounal Vol. 6, No.1:13-20

Rosalia, Naiza. (2012). Faktor-faktor Penting Daya Tarik Stasiun Radio 
Pemetaan Tata Kelola Infrastruktur...hal...66-82

Bagi Pendengar Radio Di Kota

Semarang. Jurnal Interaksi, Vol.

1, No: 1: 77-86

Theodora, N. (2013). Studi Tentang Ragam

Bahasa Gaul di Media

Elektronika Radio pada Penyiar

MemoraFm Manado. Journal

“Acta Diurna” Vol. II No. I.

Websites:

https://marketing.co.id/radio-masih-tetap-

diminati/ diakses pada 20 September 2019).

http://www.pstel.go.id/artike_c_3_-_93.htm.

Diakses pada 22 September 2019

$82 \quad \begin{aligned} & \text { Islamic Communication Journal } \\ & \text { Volume 5, Nomor 1, Januari-Juni } 2020\end{aligned}$ 